\title{
Operative outcome of Hong Kong centenarians with hip fracture
}

\author{
MY Cheung *, Angela WH Ho, SH Wong
}

\section{A B S T R A C T}

Introduction: International clinical guidelines recommend early surgical treatment for geriatric patients with hip fracture. There are, however, few data concerning the operative outcome of centenarians. This study aimed to report the epidemiology of hip fracture and postoperative mortality rate, and to discuss whether operation is justified in centenarians in Hong Kong.

Methods: This observational study was carried out in all public hospitals of Hong Kong. All patients aged 100 years or above who underwent hip fracture surgery in any public hospital between 1 January 2010 and 31 December 2013 were included. Their postoperative mean and median survival time was recorded.

Results: Of 114 centenarians, 96 (84\%) were female. The age of patients ranged from 100 to 109 years, with the largest number (44\%) aged 100 years. The follow-up interval ranged from 5 to 1619 days (median, 412 days; interquartile range, 683 days). The 1-month, 6-month, and 1-year mortalities were $8 \%, 25 \%$, and $37 \%$, respectively. By Kaplan-Meier analysis, the postoperative mean survival was 2 days) and the median survival time was 2 years (interquartile range, 1234 days).

Conclusion: The 1-year mortality among Hong Kong centenarians with hip fracture was $37 \%$, which is lower than the $41.1 \%$ in the general centenarian population in Japan. The median survival time after hip fracture surgery was 2 years, suggesting that surgery even at an extreme age is worthwhile to maintain quality of life. Extreme age should not be a barrier to operative treatment.

\section{Hong Kong Med J 2017;23:63-6}

DOI: $10.12809 / \mathrm{hkmj} 164823$

MY Cheung *, MB, ChB

AWH Ho, FHKCOS, FHKAM (Orthopaedic Surgery)

SH Wong, FHKCOS, FHKAM (Orthopaedic Surgery)

Department of Orthopaedics and Traumatology, Caritas Medical Centre, Shamshuipo, Hong Kong

An earlier version of this paper was presented as Free Paper Oral Presentation at the 34th Annual Congress of the Hong Kong Orthopaedic Association held in Hong Kong on 16 November 2014. years 2 months (95\% confidence interval, 680-936 * Corresponding author: jessicacheungmy@gmail.com

New knowledge added by this study

- The postoperative 1-year mortality among Hong Kong centenarians with hip fracture was comparable to that of the general centenarian population in Japan.

- The median postoperative survival time of the centenarians in this study was 2 years.

Implications for clinical practice or policy

- Operative treatment should be offered to centenarians with hip fracture to maintain their quality of life. Extreme age should not be a barrier to hip fracture surgery.

\section{Introduction}

Fragility fracture is one of the common chronic diseases in geriatrics. The prevalence of femoral neck osteoporosis based on a hip T-score of $<-2.5$ was $47.8 \%$ in males and $59.1 \%$ in females in our previous study of 239 hip fractures. ${ }^{1}$ The incidence of hip fracture increases with age, and the incidence is high in the elderly ( 1639 per 100000 in men and 3012 per 100000 in women for the age-group of $\geq 85$ years). ${ }^{2,3}$ A 2015 study of geriatric hip fracture showed that there was a steady increase in the incidence of geriatric hip fracture in Hong Kong. ${ }^{4}$ The overall 30-day and 1-year mortalities were $3.01 \%$ and $18.56 \%$, respectively. Advancing age and male sex were associated with an increased mortality and a higher excess mortality rate following surgery. ${ }^{4}$
With the advances in medical technology, the population of centenarians is increasing both locally and internationally. In Hong Kong, the number of centenarians has increased 6.5 -fold over the last 30 years, from 289 in 1981 to 1890 in 2011 (about 3/10000). ${ }^{5}$ Hong Kong women have overtaken Japanese women for longevity, with an average life expectancy reaching 87.32 years in 2015 compared with 87.02 years in Japan, according to statistics from Japan's Ministry of Health, Labour and Welfare. ${ }^{6}$ Advanced medical service and easy access to emergency services may contribute to this longevity. International clinical guidelines recommend early surgical treatment for geriatric patients with hip fracture once their medical condition has been optimised with the help of a geriatrician. ${ }^{7}$ There 


\section{香港百歲以上長者進行髖關節骨折手術後的結果 張美昕、何穎恆、黃仕雄}

引言：國際臨床指引建議應盡早為老年髖關節骨折患者施行手術。然 而, 有關百歲以上長者手術結果的數據廖廖可數。本研究旨在報告百 歲以上髀關節骨折長者的流行病學和術後死亡率, 從而討論應否為這 群組進行有關手術。

方法：這觀察研究於香港公立醫院進行。所有在 2010 年 1 月 1 日至 2013 年12月 31 日期間患有髖關節骨折的百歲以上長者均被列入研究範 圍。研究有關病人術後的平均存活期及其中位數。

結果：共114位百歲或以上長者被納入研究範圍, 當中96位 $(84 \%)$ 為女性。病人年齡介乎 100 至 109 歲, 當中 100 歲的長者佔 $44 \%$ 。隨訪 期由 5 日至 1619 日不等（中位數 412 日；四分位距 683 日）。病人術後 的 1 個月、6個月及 1 年死亡率分別為 $8 \%$ 、25\%及 $37 \%$. Kaplan-Meier 存活曲線分析結果顯示術後生存率平均為兩年零兩個月（95\%置信區 間：680至936日），中位數為兩年（四分位距：1234日）。

結論：香港百歲以上髖關節骨折長者的術後一年死亡率為 $37 \%$, 與日 本一般百歲以上長者的死亡率 $(41.1 \%)$ 相若。此外, 他們術後平均 壽命為兩年, 由此可見, 為他們進行䯣關節骨折手術以改善生活質素 是值得的。年齡不應成為老年患者的手術障礙。

are, however, few data concerning the operative outcome of this group of oldest elderly. Although centenarians represent only a small subset of the elderly population, their number is expected to further increase. ${ }^{5}$ Therefore it is important for us to understand the surgical outcome for this particular group of patients to enable provision of the best care and effective use of limited health care resources. The aims of our study were to report the epidemiology of hip fracture and postoperative mortality rate, and to discuss whether surgery is justified in this group of patients.

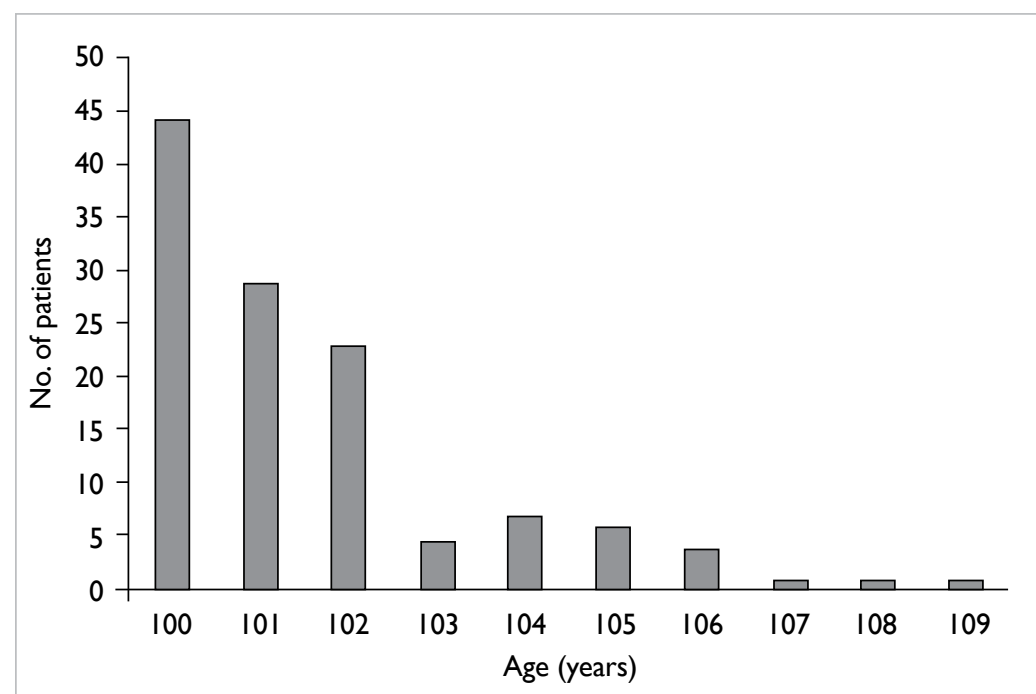

FIG I. Age distribution of centenarian hip fracture patients

\section{Methods}

This was an observational study of all patients aged 100 years or above who underwent hip fracture surgery in any public hospital in Hong Kong between 1 January 2010 and 31 December 2013. This study was done in accordance with the principles outlined in the Declaration of Helsinki. Data were retrieved from the Hospital Authority clinical database that included $99 \%$ of geriatric patients with hip fracture in Hong Kong. ${ }^{8,9}$ Patients with hip fracture aged 100 years or above were extracted from the Clinical Data Analysis and Reporting System using International Classification of Diseases code 820 under subdivision Operation Theatre Management System-linked diagnosis. Complications of initial hip surgery or periprosthetic fractures were excluded. Demographics, type of operation, and dates of admission, discharge, and death were retrieved. Mortality of the general population was retrieved using census data and the death registry of Hong Kong Special Administrative Region.

Data are shown as mean and 95\% confidence interval, or median and interquartile range. Mortality and survival were calculated using KaplanMeier survival analysis. Analyses were performed using the Statistical Package for the Social Sciences (Windows version 16.0; SPSS Inc, Chicago [IL], US). Comparative tests between different groups were performed using Chi squared test. A P value of $<0.05$ was considered statistically significant.

\section{Results}

During the 4-year study period, 114 centenarians underwent surgery in Hong Kong for primary hip fracture, of whom 96 (84\%) were female. The age of patients ranged from 100 to 109 years, with the largest number (44\%) aged 100 years (Fig 1). The largest number of patients were admitted to hospitals in Kowloon West Cluster, and this accounted for 25\%. Most were residents in the Eastern district (12\%) and Sham Shui Po (11\%) before admission. Overall, 62 (54\%) patients were admitted from elderly care homes. Hip fracture surgery was performed as an emergency in $76(67 \%)$ patients. Closed reduction and internal fixation of the femur was performed in 80 (70\%) patients, partial hip replacement in 28 (25\%), and other hip surgery in six (5\%). Postoperative admission to an intensive care unit (ICU) or high dependency unit (HDU) was necessary in two patients. The mean length of stay in an acute ward was 13.3 days, with a median of 10.5 days.

Postoperative follow-up ranged from 5 to 1619 days (median, 412 days; interquartile range, 683 days). The 1-month, 6-month, and 1-year mortality rates were $8 \%, 25 \%$, and $37 \%$, respectively (Table 1 ). By Kaplan-Meier analysis, the postoperative mean survival was 2 years 2 months (95\% confidence 
interval, 680-936 days) and the median survival time was 2 years (interquartile range, 1234 days) [Fig 2].

\section{Discussion}

With an increase in life expectancy, the health care authority is likely to encounter more elderly patients with hip fracture. The cost of providing clinical care for centenarians imposes a substantial financial burden on our health care system. There are only a few publications that specifically examine the surgical outcome of centenarians following hip fracture surgery. Due to their limited sample size, these studies have failed to justify the need to operate on centenarians with hip fracture. A previous report by Tarity et $\mathrm{al}^{10}$ on 23 centenarians reported a 1 -year mortality of $60 \%$ and concluded that operating on patients $>100$ years carried an acceptable mortality rate. Patil et $\mathrm{al}^{11}$ reported a high mobility rate of $77 \%$ and a low mortality rate of $8.3 \%$ in 13 centenarians, and concluded that hip fracture surgery yielded a good return on money spent and quality of life. Shabat et $\mathrm{al}^{12}$ reported a mortality rate of $48 \%$ in 23 centenarians and concluded that operated cases had shorter hospitalisation and patients with two or more co-morbid diseases had a higher mortality rate. Only one prospective review has reported the surgical outcome of patients aged $\geq 95$ years with the largest sample size of 50 patients. ${ }^{13}$ They reported a mortality rate of $36 \%$ that was higher than that of a younger age-group. Predictors of mortality included the American Society of Anesthesiologists physical status classification system, number of comorbidities, and active medical problems. Despite numerous studies in different parts of the world, there are no data for Asian patients.

In our study, the postoperative 1-year mortality rate for centenarians with hip fracture was $37 \%$. The postoperative mortality rate of centenarians was higher than that of hip fracture patients aged $>65$ years. ${ }^{4}$ The mortality rate in this study was similar to that of the abovementioned studies. Nonetheless, Hong Kong is one of the countries/regions with the longest life expectancy, and we had the largest sample size of 114 patients compared with previous studies (Table $2^{10-13}$ ).

Although two centenarians required ICU or HDU admission during their hospital stay, the postoperative 1-year mortality of $37 \%$ in our study is lower than the $41.1 \%$ for a general centenarian population in Japan $(\mathrm{P}<0.05) .{ }^{14}$ Those patients in our study also had a reasonable median postoperative survival of 2 years.

Previous studies have shown that the benefits of surgery are not confined to improving mobility, it also reduces other related complications, improves patient care, and is more cost-effective than other non-surgical treatments. ${ }^{15-17}$ Early multidisciplinary geriatric care also reduces in-hospital mortality
TABLE I. Mortality at different time points for centenarians who underwent surgery for hip fracture

\begin{tabular}{lccc}
\hline & \multicolumn{3}{c}{ Duration } \\
\cline { 2 - 4 } & 1 Month & 6 Months & 1 Year \\
\hline Male & $0 \%$ & $16.7 \%$ & $44.4 \%$ \\
Female & $9.4 \%$ & $26.0 \%$ & $35.4 \%$ \\
Total & $\mathbf{8 \%}$ & $\mathbf{2 5 \%}$ & $\mathbf{3 7 \%}$ \\
\hline
\end{tabular}

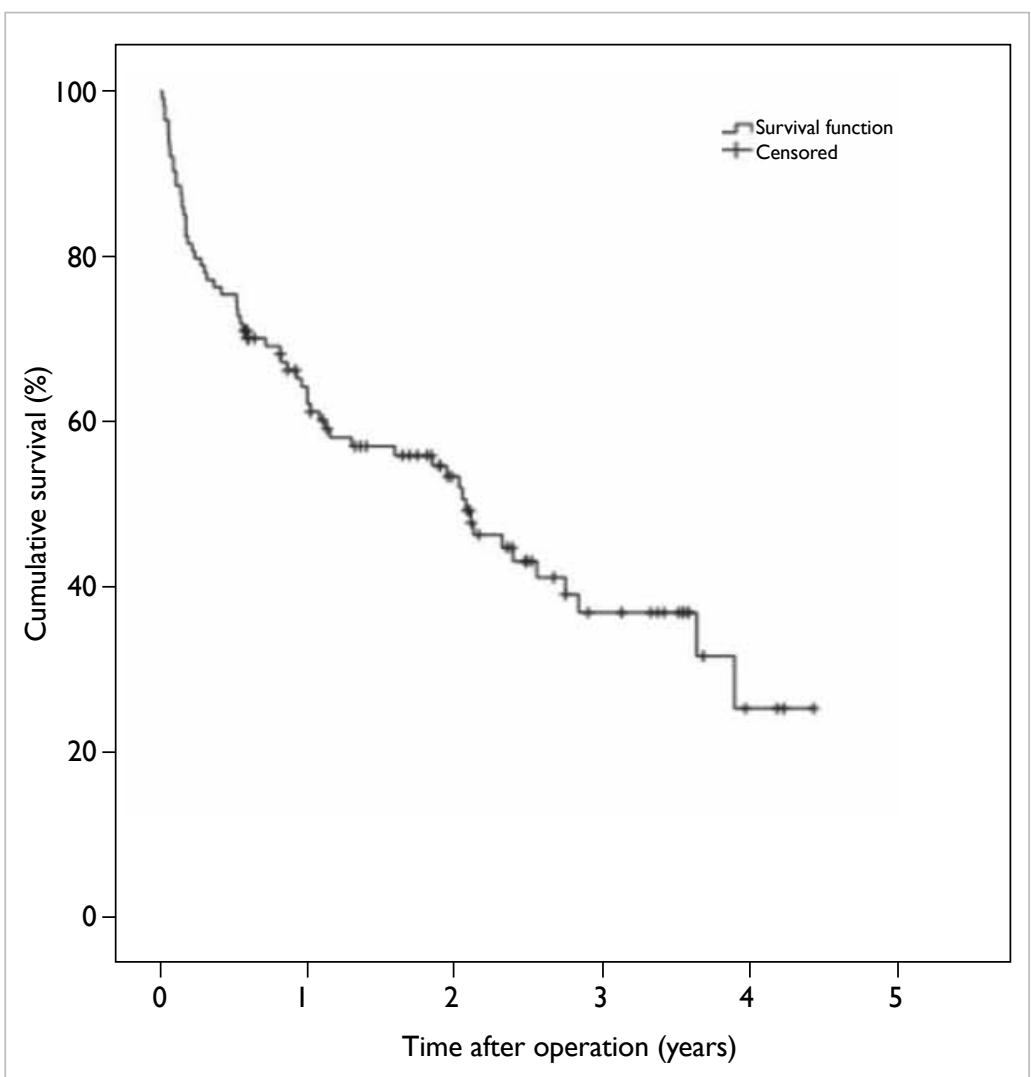

FIG 2. Kaplan-Meier survival curve of postoperative survival in centenarian hip fracture patients

The postoperative mean and median survival time was 2 years 2 months and 2 years, respectively (95\% confidence interval, 680-936 days and 519-994 days, respectively)

and medical complications. ${ }^{18}$ Patients who have undergone hip fracture surgery can be transferred from an acute unit to rehabilitation as soon as they are medically stable. In this study, the mean length of stay on an acute ward was 13.3 days. Weight-bearing walking exercises can be initiated immediately after surgery so minimising complications related to being bedbound. This will also lower the inevitable costs of acute hospital care. Some of the centenarians in our study were able to walk independently with aid following rehabilitation. One of the most encouraging cases was a 104-year-old woman who underwent dynamic hip screw fixation surgery with subsequent cut-out and converted to cemented unipolar hemiarthroplasty 1 month after the initial operation. She was able to walk well with a frame after 2 weeks of rehabilitation and was finally 
TABLE 2. Comparison of different studies concerning the surgical outcome for centenarians who underwent surgery for hip fracture

\begin{tabular}{|c|c|c|c|c|c|}
\hline & Shabat et al, ${ }^{12} 2004$ & Holt et al, ${ }^{13} 2006$ & Patil et al,, 2012 & Tarity et al, ${ }^{10} 2013$ & Present study, 2017 \\
\hline Study nature & Retrospective & Prospective & Retrospective & Retrospective & Observation \\
\hline Patient age (years) & $\geq 100$ & $\geq 95$ & $\geq 100$ & $\geq 100$ & $\geq 100$ \\
\hline Country/ethnics & Israel & UK & US & US & Hong Kong SAR, China \\
\hline No. of patients & 23 & 50 & 13 & 23 & 114 \\
\hline 1-Year mortality & $48 \%$ & $36 \%$ & $8.3 \%$ & $60 \%$ & $37 \%$ \\
\hline Conclusion & $\begin{array}{l}\text { Operated cases had } \\
\text { shorter hospitalisation; } \\
\geq 2 \text { co-morbidities had } \\
\text { higher mortality }\end{array}$ & $\begin{array}{l}\text { Predictors of mortality } \\
\text { included the ASA } \\
\text { grade, number of co- } \\
\text { morbidities, and active } \\
\text { medical problems }\end{array}$ & $\begin{array}{l}\text { Surgery yielded a good } \\
\text { return on money spent } \\
\text { and quality of life }\end{array}$ & $\begin{array}{l}\text { Operating on patients } \\
>100 \text { years carried an } \\
\text { acceptable mortality } \\
\text { rate }\end{array}$ & $\begin{array}{l}\text { Median survival was } 2 \\
\text { years after operation. } \\
\text { Extreme age should } \\
\text { not be a barrier to hip } \\
\text { fracture operation }\end{array}$ \\
\hline
\end{tabular}

Abbreviation: ASA = American Society of Anesthesiologists

discharged home.

A limitation of our study was its observational nature rather than being a prospective randomised controlled trial. It would be unethical, however, to randomise patients to have surgery or not and the sample size would be too small to provide enough statistical power to demonstrate any significant difference for this extreme of age. To the best of our knowledge, our sample size of 114 makes it the largest study to date of the surgical outcome of centenarians undergoing hip fracture surgery (Table 2). The present study undoubtedly provides insight into the treatment of centenarians with hip fracture and should prompt further research on this topic.

\section{Conclusion}

The postoperative 1 -year mortality rate among Hong Kong centenarians with hip fracture was $37 \%$, lower than the $41.1 \%$ in the general centenarian population of Japan. Centenarians also had a reasonable median survival of 2 years after hip fracture surgery. The mean length of stay in an acute ward was only 13.3 days. Therefore, surgery for hip fracture, even at extreme age, is worthwhile to maintain quality of life for affected patients. Extreme age should not be a barrier to operative treatment.

\section{Declaration}

All authors have disclosed no conflicts of interest.

\section{References}

1. Ho AW, Lee MM, Chan EW, et al. Prevalence of presarcopenia and sarcopenia in Hong Kong Chinese geriatric patients with hip fracture and its correlation with different factors. Hong Kong Med J 2016;22:23-9.

2. Gullberg B, Johnell O, Kanis JA. World-wide projections for hip fracture. Osteoporos Int 1997;7:407-13.

3. Lau EM, Lee JK, Suriwongpaisal P, et al. The incidence of hip fracture in four Asian countries: the Asian Osteoporosis Study (AOS). Osteoporos Int 2001;12:239-43.

4. Man LP, Ho AW, Wong SH. Excess mortality for operated geriatric hip fracture in Hong Kong. Hong Kong Med J 2016;22:6-10.

5. Census and Statistics Department of the Hong Kong SAR
Government. Hong Kong Population Projections 20122041. Available from: http://www.statistics.gov.hk/pub/ B1120015052012XXXXB0100.pdf. Accessed Dec 2014.

6. Ministry of Health, Labour and Welfare, Government of Japan. Abridged life tables for Japan 2015. Available from: http://www.mhlw.go.jp/english/database/db-hw/lifetb15/ index.html. Accessed Dec 2014.

7. British Orthopaedic Association. The care of patients with fragility fracture. September 2007. Available from: http://www.fractures.com/pdf/BOA-BGS-Blue-Book.pdf. Accessed Jun 2016.

8. Lau EM, Cooper C, Wickham C, Donnan S, Barker DJ. Hip fracture in Hong Kong and Britain. Int J Epidemiol 1990;19:1119-21.

9. Lau EM, Cooper C, Fung H, Lam D, Tsang KK. Hip fracture in Hong Kong over the last decade-a comparison with the UK. J Public Health Med 1999;21:249-50.

10. Tarity TD, Smith EB, Dolan K, Rasouli MR, Maltenfort MG. Mortality in centenarians with hip fractures. Orthopedics 2013;36:e282-7.

11. Patil S, Parcells B, Balsted A, Chamberlain RS. Surgical outcome following hip fracture in patients $>100$ years old: will they ever walk again? Surg Sci 2012;3:554-9.

12. Shabat S, Mann G, Gepstein R, Fredman B, Folman Y, Nyska M. Operative treatment for hip fractures in patients 100 years of age and older: is it justified? J Orthop Trauma 2004;18:431-5.

13. Holt G, Macdonald D, Fraser M, Reece AT. Outcome after surgery for fracture of the hip in patients aged over 95 years. J Bone Joint Surg Br 2006;88:1060-4.

14. Statistics Bureau, Ministry of Internal Affairs and Communications, the Government of Japan. Statistical Handbook of Japan 2013. Available from: http://www.stat. go.jp/english/data/handbook/pdf/2013all.pdf. Accessed Dec 2014.

15. Lyons AR. Clinical outcomes and treatment of hip fractures. Am J Med 1997;103:51S-64S.

16. Simunovic N, Devereaux PJ, Sprague S, et al. Effect of early surgery after hip fracture on mortality and complications: systematic review and meta-analysis. CMAJ 2010;182:160916.

17. Parker MJ, Myles JW, Anand JK, Drewett R. Cost-benefit analysis of hip fracture treatment. J Bone Joint Surg $\mathrm{Br}$ 1992;74:261-4.

18. Vidán M, Serra JA, Moreno C, Riquelme G, Ortiz J. Efficacy of a comprehensive geriatric intervention in older patients hospitalized for hip fracture: a randomized, controlled trial. J Am Geriatr Soc 2005;53:1476-82. 